\title{
重度失語症者の非言語的象徵障害
}

\author{
竹内 愛子 ${ }^{1)}$ 高橋 正 $^{1)}$ 萩生 正彦 ${ }^{2)}$ \\ 野中 弘) 河内 十郎 ${ }^{4)}$
}

要 約 : 重度失語症者の非言語的象徵障害を検討するために 5 種の非言語課題（ 3 種の象徵 的課題と 2 種の空間的課題）を実施した。被験者は 22 名, 比較対照群は軽・中度失語群 10 名, 痴呆群 14 名であり，つぎの結果が得られた。

1) 重度群は軽・中度群に比較すると象徵的課題, 空間的課題ともに劣るが, 痴呆群に比較 すると象徵的課題だけが劣っていた。

2 ）失語群では象徵的課題と空間的課題に相関がみられた。しかし痴呆群にはこのような相 関がなかった。

3 ) 言語様式との関連をみると，3群ともに象徴的課題は言語の理解面との相関が高く，空 間的課題は書字や計算との相関が高い傾向があった。

4 ) 重度群の中で非言語能力が低いタイプは全失語, 重度ウェルニッケ失語, TCs, 最重度ブ ローカー失語などであった。

5 ）重度群の中で非言語能力が低い失語群の言語能力は, 非言語能力が低くない群に比べて 読みの理解が有意に低く，また全体的な言語能力も低かった。

以上の結果にもとづいて，重度失語症者のコミュニケーションにおける非言語的手段の導入 の問題に言及した。

索引用語：重度失語症, 非言語的象徵障害, 失語夕イプ, 非言語的コミュニケーション能力

\section{Nonverbal Cognitive Disturbance in Severe Aphasic Patients}

\section{Aiko Takeuchi ${ }^{1}$, Tadashi Takahasi ${ }^{1}$, Masahiko Hagyu $^{2}$, Hiroshi Nonaka $^{3)}$, Juro Kawachi ${ }^{4)}$}

\footnotetext{
Abstract : In order to study nonverbal cognitive ability in severe aphasic patients, five nonverbal tasks (three associative and two visuo-spatial intelligence tests) were administered to 22 severe aphasics and two control groups including 10 moderate or mild aphasics and 14 demented patients. The results were as follows :

1) Severe aphasic group scored significantly lower on both the associative and the

1) 七沢リハビリテーション病院脳血管センター言語科 : ₹ 243-01 神奈川県厚木市七沢 1304

2) 緑協和病院言語室 : 7227 神奈川県横浜市緑区奈良町 1802

3) 緑協和病院内科 : $=227$ 神奈川県横浜市緑区奈良町 1802

4) 東京大学教養学部心理学教室 : $=153$ 東京都目黒区駒場 3-8-1

1) Speech Therapy section, Nanasawa Rehabilitation Hospital, Kanagawa Rehabilitation Center : 1304 Nanasawa Atsugi-shi,

2) Speech Therapy section, Midori-Kyowa Hospital : 1802 Nara-machi Midori-ku, Yokohama-shi, Kanagawa, 227.

3) Internal Medecine section, Midori-kyowa Hospital : 1802 Nara-machi Midori-ku, Yokohama-shi, Kanagawa, 227

4) Department of Psychology, College of Arts and Sciences, University of Tokyo : 3-8-1 Komaba Meguro-ku, Tokyo, 153. 原稿受理：平成 2 年 12 月 18 日
} Kanagawa, 243-01. 
spatial intelligence tests than moderate or mild aphasic group. But compared with demented group, severe aphasic group was inferior in only the intelligence tests.

2 ) Significant correlations between the associative and the spatial intelligence tests were found in two aphasic groups, but not in demented group.

3 ) Among language subtests (modified version of S.L.T.A.), auditory and reading comprehensions had siginificant correlations with the associative tests, and writing and calculation with the spatial intelligence tests in all three groups.

4 ) Nonverbal defects were preferentially associated with global, severe Wernicke's, TCS and the most severe Broca's aphasics.

5 ) Among severe aphasics, patients with nonverbal defects were siginificantly inferior in reading comprehension and overall sore of language test to patients without nonverbal defects.

Based on these findings, nonverbal communication ability of severe aphasic patients is discussed.

Key words : severe aphasia, nonverbal cognitive disturbance, types of aphasia, nonverbal commuication ability.

\section{I 、はじめに}

近年, 失語症の臨床では語用論的観点から, 言語に だけこだわらず非言語様式も含めた多種類の手段を用 いて，コミュニケーションの改善をはかろうとする技 法が盛んである1 ${ }^{14)}$.こうした考え方は言語機能の改善 がはかばかしくない重度失語症者の臨床に希望を与え てくれるものであるが，現実には，非言語的手段を獲 得したりあるいはそれを日常コミュニケーションへ般 化する能力がほとんど期待出来ない重度失語症者はか なりのパーセントに昇ると思われる，しかし今日，こ のような非言語的手段が獲得可能な患者の特徵や条件 は明らかにされているとはいい難い.

一方, 失語症者の非言語機能をめぐる問題は, 研究 史上失語症を知能障害と考えるか, 逆にそれを合併障 害として失語症には知能障害はないと考えるかの, い わゆる知性論と反知性論の対立として論議されている 問題でもある. その詳細は最近の概説にゆずり ${ }^{5 \sim 8)}$, 本 稿ではこの非言語機能障害の問題を重度失語症者のコ ミュニケーションにかかわる臨床的問題という観点か らみていきたいと考えているが，失語症の本質を考え る上でも重要な問題でもあり, 必要に応じてそれらの 議論も加えて検討していく予定である.

\section{II. 方 法}

\section{1. 対象者}

被験者は失語重度群（以下重度群と略す） 22 名, お よび比較対照群として失語軽・中度群（以下軽・中度
群と略す) 10 名, 痴呆群 14 名である(但しテストによ って実施した人数は一定ではない)。全例右利きであ り，また石原式色盲検査，家族や本人に対する質問に よって色盲がないことが確認されている.各群の年齢, 発症後経過月数, 教育年限, 病因抢よび失語 2 群の夕 イプ別人数を表 1 に示した。痴呆群の長谷川式老人用 簡易知能スケールの成績は平均 10.1 (SD 5.6), 2.0 ２0.0 の範囲にあった. 3 群の条件のうち発症後 経過月数, 教育年限では群間に差がなく, 年齢条件の み痴呆群が失語の 2 群に比して有意に高齢となってい た（重度群との比較： $\mathrm{t}=5.17 \quad \mathrm{p}<0.01$ ).

“重度” 失語症の判定は臨床的印象と, 後述する標 準失語症検査 (SLTA) の変法の成績の両方からおこな った。重度失語症の判定基準として HelmEstabrooks ${ }^{9}$ は，ボストン失語症診断検査の 0 および 1 のレベルをあげているが，本稿の重度群もそれらの 臨床像に一致している。

\section{2. 材料}

1) 非言語検查 : 使用した非言語的課題はそれらの 特徵によって, 象徵的課題と空間的課題の $2 つ$ つテ ゴリーに分類した 5 種類である.

\section{(1) 象徵的課題}

色塗り；日常物品の線画を 1 枚ずつ提示し，それら を 12 色の色鉛筆から適切と思う色を選んで塗らせる (16 項目, 最高 16 点).

塗られた色の正誤判定 (以下色の正誤判定と略す)； 色塗りで使用した 16 個の線画のおのおのについて, 正 答を含め異なった色に塗った 4 枚の選択肢の中から正 
表 1 被験者の内訳

\begin{tabular}{|c|c|c|c|c|c|c|c|c|c|}
\hline 群 & 人数 & & 年齢 & 経過月数 & 教育年限 & 病因 & & 失語の夕イ & \\
\hline \multirow{6}{*}{ 失語重度群 } & \multirow{6}{*}{22} & \multirow{6}{*}{$\begin{array}{l}\text { 平均 } \\
\text { (SD) } \\
\text { 範囲 }\end{array}$} & 56.6 & 15.5 & 10.4 & & & ブローカ & 3 名 \\
\hline & & & & & & 脳出血 & 12 名 & 最重度ブローカ & 5 \\
\hline & & & (8.4) & (18.2) & (2.5) & & & 全失語 & 3 \\
\hline & & & & & & & & ウェルニッケ & 2 \\
\hline & & & $46 \sim 68$ & $5 \sim 91$ & $6 \sim 16$ & 脳梗塞 & 10 & 超皮質性感覚 & 3 \\
\hline & & & & & & & & 非典型 & 6 \\
\hline \multirow{3}{*}{$\begin{array}{c}\text { 失語 } \\
\text { 軽・中度群 }\end{array}$} & \multirow{3}{*}{10} & & 50.2 & 8.7 & 10.3 & 脳出血 & 7 & 失名詞 & 4 \\
\hline & & & (7.6) & (7.5) & (2.5) & & & ブローカ & 5 \\
\hline & & & $36 \sim 61$ & $2.5 \sim 23$ & $6 \sim 14$ & 脳梗塞 & 3 & ウェルニッケ & 1 \\
\hline \multirow{3}{*}{ 痴呆群 } & \multirow{3}{*}{14} & \multirow{2}{*}{\multicolumn{2}{|c|}{$\begin{array}{c}71.7 \\
(8.3)\end{array}$}} & \multirow{2}{*}{$\begin{array}{c}13.2 \\
(11.0)\end{array}$} & \multirow{2}{*}{$\begin{array}{c}9.7 \\
(2.3)\end{array}$} & 脳血管性 & 12 & & \\
\hline & & & & & & 頭部外傷 & 1 & & \\
\hline & & & $53 \sim 80$ & $3.5 \sim 38$ & $8 \sim 14$ & アルツハイマー & 1 & & \\
\hline
\end{tabular}

しいと思う色の絵を指ささせる (16 項目, 最高 16 点). ジェスチュア表出；日常物品を 1 個ずつ提示し，そ の使い方をジェスチュアで示させる (10 項目, 最高 10 点).

(2) 空間的課題

レーヴンの標準マトリックス検査 (RPM) ; 大図版 の空白部分を埋めるために $6 \sim 8$ 個の小図版の選択肢 の中から正しい図版を選ばせる市販のテスト（60 項 目, 最高 60 点).

コース立方体組合わせテスト；4～16 個の積木で 図形を構成する市販のテスト（17 項目, 最高粗点 131 点).

2 ) 言語検査 (SLTA の変法)：当院ではSLTA の 下位検查のうち 5 問題のみの検查の多くは 10 題に項 目を追加して使用しているが, さらに今回はSLTA の 中から下位検查を抽出しそのうち難易度の高い検查に は 2 倍の重みづけをおこなって以下のように得点化し た。

聴く 40 (単語 10 , 短文 10 , 口頭命令 20 ), 読む 40 (漢 字単語 5 , 仮名単語 5 , 短文 10 , 書字命令 20 , 発話 40 (呼称 20 , 動作説明 10 , まんがの説明 10 ), 復唱 30 (単 語 10 , 文 20 ), 音読 40 (漢字単語 10 , 仮名単語 10 , 仮 名一文字 10 , 短文 10 ), 書字 40 (漢字単語 10 , 仮名単 語 10 , まんがの説明 10 , 仮名一文字書取 10), 以上の 6 種類の様式の合計点 230 . 計算 30 (加減算 10 , 乗除 算 20）は，一般的な言語様式に比べて空間操作能力の 関わりが大きいと予測されるため, 上記の合計点には 含めず別立てとした。このようにして SLTA の成績は 7 種類の言語様式に分け検討の対象とした。

1 回の検查時間は $30 \sim 60$ 分程度で, 非言語検査は全
種類を $3 \sim 4$ 回に, SLTA は $2 \sim 3$ 回に分けて実施し た.

3 ）色塗りの判定基準の設定：日常物品の色の記号 化は健常者の場合でも必ずしも一色とは限らないこと が多い. そこで 23 名 (23 81 歳) の健常者に本稿のテ ストと同じ色塗り課題を実施した。さらに他の 32 名 (20〜68 歳)には実際に塗る作業はおこなわせず, 質問 紙のかたちで当該の物品の色として適切と思う色を， 列挙してある 12 の色名の中からえらんでしるしを付 けさせた，以上 55 名の健常者の反応のうち 10 パーセ ント以上の者が選んだ色を当該の物品の色として正反 応とする方法をとった。

\section{III. 結 果}

\section{1. 非言語成績の比較}

重度群および対照群の成績を図 1 に示した。 3 群間 で差がなかったのは色の正誤判定だけで，この課題で

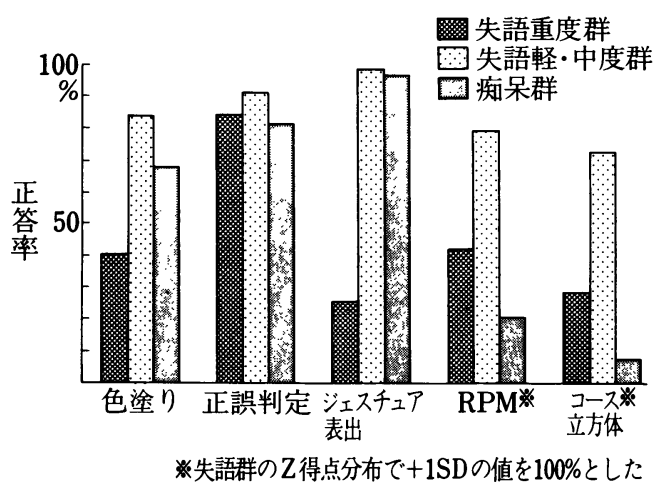

図 1 非言語成績の比較 


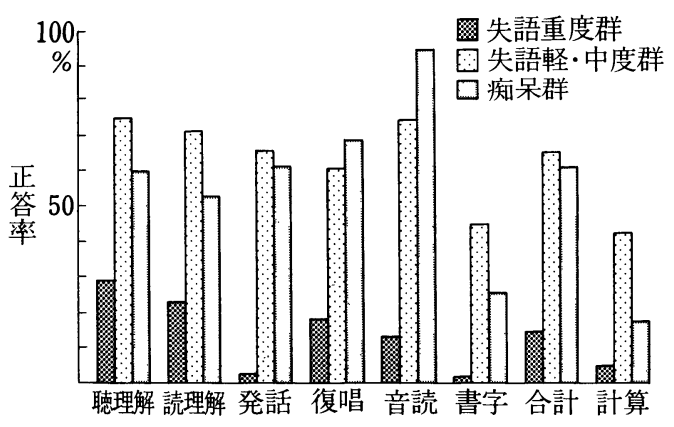

図 2 言語成績の比較

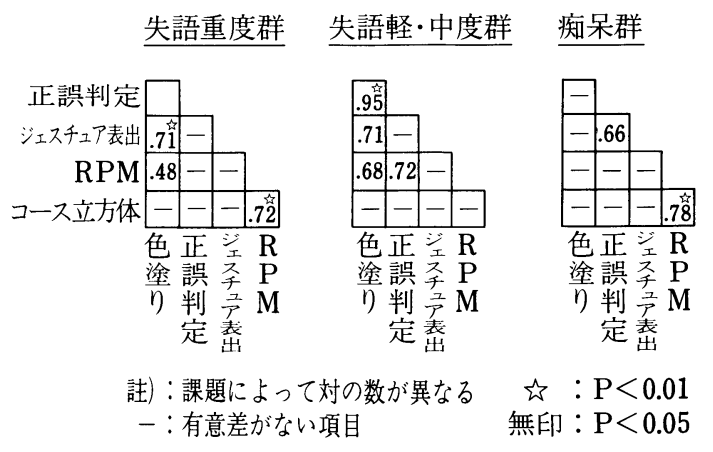

図 3 非言語課題間の相関
は重度群も 13.4 の得点 (83.8 パーセントの正答率)を 示した. しかし他の 4 種の課題についてみると, 重度 群は軽・中度群に有意に劣っていた（色塗り $\mathrm{t}=4.04$ $\mathrm{p}<0.01$, ジェスチュア表出 $\mathrm{t}=8.63 \mathrm{p}<0.01, \mathrm{RPM}$ $\mathrm{t}=3.14 \mathrm{p}<0.01$, コース立方体 $\mathrm{t}=2.38 \mathrm{p}<0.05)$. また痴呆群と比較すると, 象徴的課題の色塗りとジェ スチュア表出では重度群が劣っていたが(色塗り $\mathrm{t}=$ $3.06 \mathrm{p}<0.01$, ジェスチュア表出 $\mathrm{t}=7.97 \mathrm{p}<$ $0.01)$, 空間的課題では、RPM では重度群の方が逆に 優れており $(\mathrm{t}=4.32 \mathrm{p}<0.01)$, コース立方体では 2 群間に差がなかった。

対照の 2 群間を比較すると, 色塗りとジェスチュア 表出の象徵的課題では差がないが, 空間的課題では上 の結果からも推察される通り痴呆群は軽・中度群に劣 っていた（RPM $\mathrm{t}=5.90 \mathrm{p}<0.01$, コース立方体 $\mathrm{t}=4.09 \mathrm{p}<0.01)$.

\section{2. 言語成績の比較}

重度群および対照 2 群の成績を図 2 に示した。当然 のことながら重度群の成績はすべての言語様式で軽・ 中度群より極端に低く，また痴呆群に比較すると書字 と計算では 2 群間に差がなく, その他の様式では重度 群が劣つていた。

\section{3. 非言語課題間の比較}

重度群および対照群について非言語課題間の相関を 図 3 に示した。課題による対の人数は $22 \sim 9$ と異なっ ているが, 9 人と少ないのは 3 群で合計 30 個の組合わ せ中, 重度群では 1 個（正誤判定とジェスチュアの組 合わせ）のみで, 軽・中度群に 7 個あった。

まず色塗りについてみると, 重度群と軽・中度群は ともにジェスチュア表出とも RPM とも有意な相関を 示している．また色の正誤判定では，軽・中度群では $\mathrm{r}=0.95$ の高い相関係数が出ている. 重度群でも $\mathrm{r}=$ $0.53(\mathrm{~N}=13)$ だがわずかに有意水準を下回った。軽・ 中度群ではこの色の正誤判定と RPM にも有意な相関
があったが, 重度群では低いものとなっている.一方, RPM とコース立方体の空間課題間の相関は重度群で は有意であり, 軽・中度群でも $\mathrm{r}=0.50(\mathrm{~N}=9)$ とな っている. 以上から, 失語の 2 群では非言語課題が象 徵的か空間的かによって成績が解離せず相関を示し, この傾向は失語の重症度によって異ならないという結 果を得た。

痴呆群では色の正誤判定とジェスチュア表出間の相 関が有意で, 色塗りとジェスチュア表出間でも $\mathrm{r}=$ $0.58(\mathrm{~N}=10)$ であった。 また RPM とコース立方体間 にも有意な相関があるが, 象徵的課題と空間的課題の 相関は低いものとなっており, さきの失語 2 群とは異 なった傾向を示した。

\section{4. 非言語成績と言語成績の比較}

非言語課題のうち象徵的課題として色塗り, 空間的 課題として RPM をとりあげ，それらの成績と様式別 の言語成績を比較した（表 2 ）。

色塗りでは失語の 2 群は聴理解および読みの理解の 2 つの理解面と有意な相関を示した. 痴呆群では読み の理解とだけ有意な相関が出ているが, 聴理解とも $\mathrm{r}=0.60(\mathrm{~N}=10)$ と有意水準に近い值となっている. このように色塗りは 3 群ともに理解面と相関が高い傾 向を示した. 発話面とは痴呆群のみが高い相関があり 失語 2 群の值は低いものとなっている. 復唱や音読面 とはいずれの群も有意な相関がなかった．書字と言語 の合計点では, 重度群と痴呆群が有意な相関を示して いる.また,この課題では計算面と相関を示した群は なかった。

RPM では, 理解面と有意な相関を示す群が減少し, 重度群の読みの理解とだけが有意であった。軽・中度 群も読みの理解とでは $\mathrm{r}=0.52(\mathrm{~N}=10)$ で, 有意では ないが比較的高い. しかし聴理解との相関は 2 群とも 低くなっている. 痴呆群では聴理解と $\mathrm{r}=0.55$, 読みの 理解と $\mathrm{r}=0.60$ (いずれも $\mathrm{N}=10$ ) であるがいずれも有 
表 2 非言語と言語の成績の相関

色塗り

\begin{tabular}{|c|c|c|c|c|c|c|c|c|c|}
\hline \multirow{2}{*}{ 群 } & \multirow{2}{*}{$\mathrm{N}$} & \multirow{2}{*}{ 聴 } & \multirow{2}{*}{$\begin{array}{l}\text { 読 } \\
\text { 理 } \\
\text { 解 }\end{array}$} & \multirow{2}{*}{$\begin{array}{l}\text { 発 } \\
\text { 話 }\end{array}$} & \multirow{2}{*}{$\begin{array}{l}\text { 復 } \\
\text { 唱 }\end{array}$} & \multirow{2}{*}{$\begin{array}{l}\text { 音 } \\
\text { 読 }\end{array}$} & \multirow{2}{*}{$\begin{array}{l}\text { 書 } \\
\text { 字 }\end{array}$} & \multirow{2}{*}{$\begin{array}{l}\text { 合 } \\
\text { 計 }\end{array}$} & \multirow{2}{*}{$\begin{array}{l}\text { 計 } \\
\text { 算 }\end{array}$} \\
\hline & & & & & & & & & \\
\hline 失語重度群 & 22 & .44 & .64 药 & - & - & - & .51 & .41 & - \\
\hline 失語軽・中群 & 10 & .64 & .71 & - & - & - & - & - & - \\
\hline 痴呆 & 10 & - & .66 & $.84^{\text {म }}$ & - & - & .63 & .74 & - \\
\hline \multicolumn{10}{|l|}{ RPM } \\
\hline 失語重度群 & 22 & - & $.64^{\text {h }}$ & - & - & - & .58 & 45 & .66 \\
\hline 失語軽・中群 & 10 & - & - & - & - & - & - & - & .66 \\
\hline 呆 & 10 & - & - & - & - & - & $.90^{\text {占 }}$ & - & $.82^{\text {㟧 }}$ \\
\hline \multicolumn{7}{|c|}{ 註）一 有意差がない項目 } & & & $\begin{array}{l}.01 \\
.05\end{array}$ \\
\hline
\end{tabular}

表 3 非言語成績と失語タイプ（重度群）

\begin{tabular}{|c|c|c|c|c|c|c|c|c|c|c|c|}
\hline \multicolumn{2}{|c|}{ 課 題 } & \multicolumn{2}{|c|}{ 色塗り } & \multicolumn{2}{|c|}{ 正誤判定 } & \multicolumn{2}{|c|}{ ジェスチュア表出 } & \multicolumn{2}{|c|}{ RPM } & \multicolumn{2}{|c|}{ コース立方体 } \\
\hline \multicolumn{2}{|c|}{$\mathrm{N}$} & \multicolumn{2}{|c|}{22 名 } & \multicolumn{2}{|c|}{13} & \multicolumn{2}{|c|}{12} & \multicolumn{2}{|c|}{22} & \multicolumn{2}{|c|}{17} \\
\hline \multicolumn{2}{|c|}{$\begin{array}{l}\text { 平均 } \\
\text { (SD) }\end{array}$} & \multicolumn{2}{|c|}{$\begin{array}{c}6.6 \\
(4.5)\end{array}$} & \multicolumn{2}{|c|}{$\begin{array}{l}13.4 \\
(1.5)\end{array}$} & \multicolumn{2}{|c|}{$\begin{array}{c}2.6 \\
(2.8)\end{array}$} & \multicolumn{2}{|c|}{$\begin{array}{l}15.4 \\
(9.1)\end{array}$} & \multicolumn{2}{|c|}{$\begin{array}{c}21.6 \\
(30.2)\end{array}$} \\
\hline \multirow{7}{*}{ 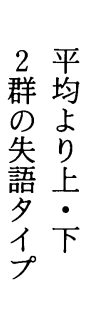 } & & 上 & 下群 & & & & & & & & \\
\hline & B & 2 & 1 & 1 & 0 & 2 & 0 & 3 & 0 & 2 & 1 \\
\hline & $\mathrm{B}^{\prime}$ & 2 & 3 & 2 & 1 & 0 & 1 & 1 & 4 & 0 & 2 \\
\hline & $\mathrm{U}$ & 5 & 1 & 2 & 1 & 2 & 2 & 4 & 2 & 4 & 0 \\
\hline & $\mathrm{T}$ & 0 & 3 & 1 & 2 & 0 & 2 & 0 & 3 & 0 & 3 \\
\hline & W & 1 & 1 & 0 & 1 & 1 & 1 & 0 & 2 & 0 & 2 \\
\hline & TCS & 0 & 3 & 0 & 2 & 0 & 1 & 0 & 3 & 0 & 3 \\
\hline \multicolumn{2}{|c|}{ 両群のN } & 10 & 12 & 6 & 7 & 5 & 7 & 8 & 14 & 6 & 11 \\
\hline
\end{tabular}

註） $\mathrm{B}$ ブローカ失語, $\mathrm{B}^{\prime}$ 最重度ブローカ失語, $\mathrm{U}$ 非典型例, $\mathrm{T}$ 全失語, $\mathrm{W}$ ウェルニッケ失語 TCS 超皮質性感覚失語

意ではない。書字面とでは, 重度群と疾呆群が有意な 相関を示したが，言語の合計点では重度群との相関だ けが有意であった。一方目立つのは計算面で 3 群とも が有意な相関を示したことであり、この傾向は色塗り ではみられなかったものである。

\section{5. 非言語成績が低い重度失語症者の特徵}

この項では重度群の各課題の成績の平均値をとり, その值より成績が高い上群と逆に低い下群の 2 群に分 けて.非言語機能がとくに低い失語症者の検討を行う。

1) 失語タイプ: 5 種の非言語課題について, 重度
上群と下群における失語タイプの出現人数を表 3 に示 した.表中に記したように検査によって人数が異なり， またタイプに分けると各タイプの人数も非常に少なく なるので, 明確にはいいがたい部分が残るが, 非言語 機能と失語タイプの関係についての全体的傾向はみる ことはできる.

重度上群に出現傾向が強いのはブローカ失語と非典 型例であった. また最重度ブローカ（B'）と表記した ブローカ失語様でも非常に重いタイプの場合はむしろ 下群の方が多い傾向があった。 その他に重度下群に出 
現傾向が強いのは, 全失語, ウェルニッケ失語, 超皮 質性感覚失語 (TCS) の各タイプがあった.

2 ) 非言語成績の比較: 図 4 に重度上・下群と対照 2 群の非言語成績を示した。課題のうち色の正誤判定 は平均得点が上群 14.7 , 下群 12.3 と 2 群間に差がな かったので図からは除外してある. 他の 4 種の課題で は重度上群と下群の差は明らかである.一方重度上群 を軽・中度群に比較するとジェスチュア表出にだけ差 があり $(\mathrm{t}=6.82 \mathrm{p}<0.01)$, 重度上群が劣るが, 色塗 り, RPM, コース立方体では 2 群間に差がなく, 重度 上群もよい成績であった。

3 ）言語様式における特徴：色塗りとRPM の成績 による重度上・下群について言語成績の特徵を比較検 討した (表 4 ).

2 つの課題ともに 2 群間で差がみられたのは読みの 理解（色塗り $\mathrm{t}=2.22 \mathrm{p}<0.05, \mathrm{RPM} \mathrm{t}=3.25 \mathrm{p}<$ 0.01 ) と言語の合計点（同じ課題順で $\mathrm{t}=2.15 \mathrm{p}<$

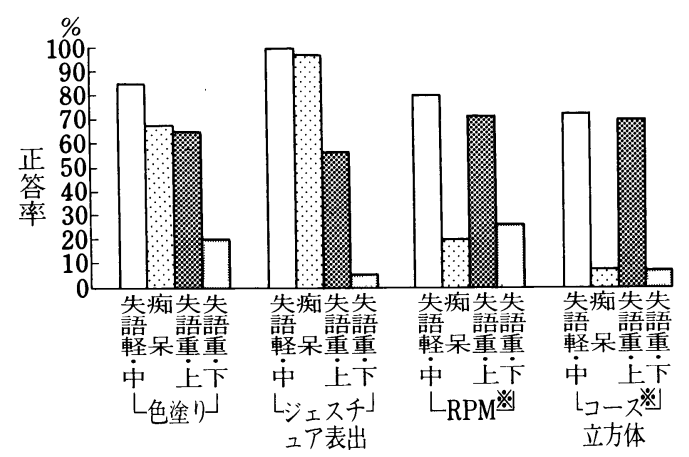

※失語群のZ得点分布で+1SDの值を $100 \%$ とした

図4 重度群を 2 群にわけた場合の非言語成績の 比較
$0.05, \mathrm{t}=2.27 \mathrm{p}<0.05)$ であった。また RPM では計 算でも差が明らかであった $(\mathrm{t}=3.22 \mathrm{p}<0.01)$.

4 ) 色塗り課題における誤反応の特徵：非言語課題 のうちから色塗りをとりあげて誤り方の内容を分析 し, 重度群の非言語機能の特徵の把握を試みた.

(1) 誤り方の一貫性; 同じ色塗りを 2 回実施 (1 〜 6 カ月の間隔) した重度群 8 名について, 色の想起 の誤り方に一貫性があるかを調べた。これら 8 名の 1 回目検査時の誤りはおのおの 16 枚の線画中 $4 \sim 16$ 枚 で合計 83 個, 2 回目は $4 \sim 11$ 枚で合計 80 個であっ た.これらの誤数のうち 8 名が一貫して誤ったのはお のおの $0 \sim 2$ 枚合計 10 個にすぎず, 誤り方に一貫性の ない傾向が伺えた。

(2) 総誤反応に占める保続・未分化反応の出現率; 分析の対象とした保続反応は直前の線画に用いた色を 次の絵でも不適切に使用する反応とし，また未分化反 応は同じ 1 枚の線画の中の異なった部分を同じ色に塗 る反応とした．例えば桜の花の線画で葉や枝も花と同 じ色に塗る反応はこれに該当する.しかし色塗り課題 では絵の細部はその存在に気づかず塗らない者もいた ので, 今までの色塗り課題分析では採点の対象とはし ていない.

図 5 の(A)は採点対象とした絵の部分についての誤反 応を示したものである。この課題では 1 枚の絵が 2 色 にわかれるものは 16 枚中 2 枚にすぎなかったので, 未 分化反応の出現個数が非常に少なく, 図のように保 続・未分化反応としてまとめた。

まず総誤り率の 4 群間の差は明らかであった $\left(\chi^{2}=\right.$ $170.9 \mathrm{p}<0.01)$.これは重度下群が他の 3 群に比べ て誤りが多いためであり（下群についで誤数が多い重 度上群との比較で $\mathrm{t}=5.03 \mathrm{p}<0.01)$, この差は図 4

表 4 非言語成績の異なる 2 群の言語成績の比較（重度群）

\begin{tabular}{|c|c|c|c|c|c|c|c|}
\hline \multicolumn{5}{|c|}{ 色 塗 り } & \multicolumn{3}{|l|}{$\mathrm{R} \quad \mathrm{P} \quad \mathrm{M}$} \\
\hline $\begin{array}{l}\text { SLTA } \\
\text { (変法) }\end{array}$ & 最高点 & $\begin{array}{l}\text { 上群（10 名） } \\
\text { 平均 (SD) }\end{array}$ & 下群（12 名） & $\mathrm{P}$ & $\begin{array}{l}\text { 上群 (8 名) } \\
\text { 平均 (SD) }\end{array}$ & 下群（14 名） & $\mathrm{P}$ \\
\hline 聴理解 & 40 & $13.8(7.2)$ & $9.7(5.7)$ & & $14.0(7.9)$ & $10.1(5.6)$ & \\
\hline 読理解 & 40 & $11.9(5.1)$ & $7.0(4.9)$ & $*$ & $13.5(4.8)$ & $6.8(4.3)$ & is \\
\hline 発 話 & 40 & $1.7(2.7)$ & $0.6(1.2)$ & & $1.8(2.5)$ & $0.7(1.7)$ & \\
\hline 復 唱 & 30 & $7.3(5.6)$ & $3.8(4.1)$ & & $5.4(5.8)$ & $5.4(4.8)$ & \\
\hline 音＼cjkstart読 & 40 & $4.6(8.0)$ & $5.8(10.2)$ & & $6.3(9.4)$ & $4.6(9.1)$ & \\
\hline 書＼cjkstart字 & 40 & $1.7(3.3)$ & $0.1 \quad(0.3)$ & & $2.1(3.6)$ & $0.1 \quad(0.3)$ & \\
\hline 合 計 & 230 & $41.1(14.0)$ & $26.8(15.5)$ & $*$ & $43.1(15.4)$ & $27.7(14.3)$ & $*$ \\
\hline 計 算 & 30 & $2.1(3.3)$ & $0.8(1.6)$ & & $3.4 \quad(3.3)$ & $0.3 \quad(0.8)$ & 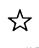 \\
\hline
\end{tabular}

必 $\mathrm{P}<0.01 * \mathrm{P}<0.05$ 


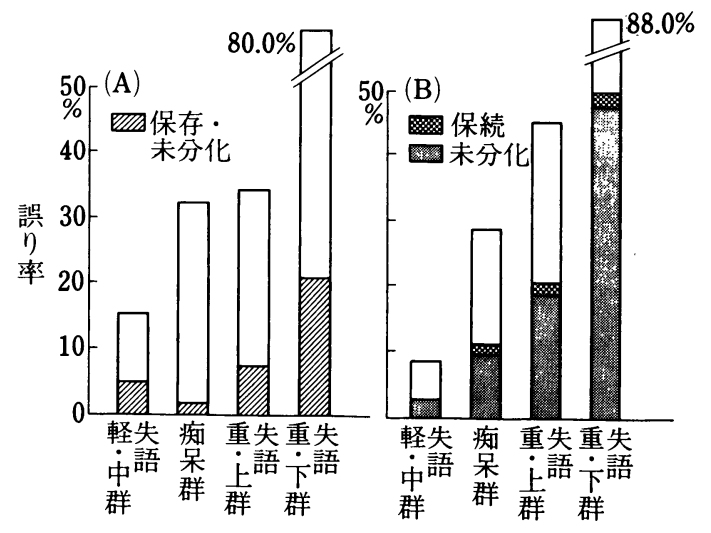

図 5 総誤反応に占める保続・未分化反応の出現率 (A)色塗りの誤り・(B) 細部での誤り方

からも推測される通りである。また総誤反応中に占め る保続・未分化反応の出現率でも 4 群間に差があった $\left(\chi^{2}=15.1 \mathrm{p}<0.01\right)$.これは失語の 3 群間ではこの 種の反応の出現率が $20 \sim 30$ パーセント程度あるのに 対して, 痴呆群だけが 5.6 パーセントと少ないためで, 失語の 3 群間で比較すると差がなかった。

図 5 の(B)には線画の細部での色塗りの誤反応を示し た. 4 群間の総誤り率は有意に異なっており $\left(x^{2}=\right.$ $81.02 \mathrm{p}<0.01)$, 重度下群は 88.0 パーセントと高い 誤り率を示している. 保続と末分化反応は, 図 $5(\mathrm{~A})$ と は異なって, 保続は非常に少なくほとんどが未分化反 応となっている．総誤数に占める未分化反応に保続を 加えた反応の出現率は, 軽・中度群 33.3, 疾呆群 39.1, 重度上群 45.8 , 重度下群 56.1 パーセントとなってお り, 重度下群でのこれらの反応は誤反応の半数以上を 占めるものの 4 群間の差は有意に達しなかった。

\section{IV. 考察}

失語症者の非言語機能に関する研究でしばしば使用 される課題に次の 3 種がある. 即ち(1) RPM, WAIS 動 作性, コース立方体などのこうした課題ではいわゆる 動作性知能テスト. 空間的な認知構成能力が重要な要 因となる. (2)非言語項目と意味的, 概念的に対応する 他の非言語項目を連合させる課題. たとえばジェスチ ュアをみてそれの示す実物や絵を指さす課題はこの種 のものである.こうした課題を遂行するには当該の非 言語項目の意味を理解しその特徵や属性を知っている 必要がある点で象徵的課題ということができる. (3)分 類テストと呼ばれるさまざまな課題. 古くは Weigl の テストから意味機能・抽象化機能を調査するための今 日的テストまでさまざまなテストが工夫されている.
本稿ではこれらの材料のうち(1)と(2)の種類に該当す る課題を用いて, 重度失語症者の非言語機能の検討を おこなった。また対照群として軽・中度失語群のほか に痴呆群を加えたが，この群では広範囲な認知機能の 障害が認められており ${ }^{10}$ 重度失語症者との認知の違い を検討の中に加えた。

\section{1. 重度失語群の非言語能力}

重度群は課題としてやさしかった色の正誤判定を除 いた象徵的課題では, 軽・中度群および痴呆群より劣 り, 空間的課題では軽・中度群にはやはり劣るが, 痴 呆群とは差がないかむしろやや優れているといった成 績を示した。

失語症者の非言語能力が言語の重症度と平行するか どうかの問題は, 研究者たちの失語症観によって議論 に一致がないのが現状である. 失語症は言語・非言語 の両領域にわたる失象徴であるとする Finkelnburg ${ }^{11}$ の考え方を復活させた Duffy らはもちろんのこと, 失 語の重症度と非言語能力の対応を主張してい $3^{12 \sim 15)}$. 一方, 失語の重症度と非言語能力は平行しな いとする議論は, 研究者の主張する仮説によって一様 ではないが，少なくとも両者の対応関係を認めていな い点では一致している ${ }^{5 \sim 8)}$. 竹内ら ${ }^{16 \sim 18)}$, 河内も ${ }^{6,19)}$ 重 度失語群の中に少数だが非言語能力が非常に高い者が おり, その能力が必ずしも失語の重症度と平行しない という結果を得ている. 本稿の重度群 22 例の中にも $\mathrm{RPM}$ とコース立方体の空間的課題の成績が軽・中度 群の平均よりも高い 2 例があった。 1 例 $(\mathrm{K} \cdot \mathrm{M})$ はブ ローカ失語で, 成績を粗点で示すと色浩り $14 / 16$, 色の 正誤判定 15/16, ジェスチュア表出 7/10, RPM 31/60, コース立方体 93/131 となっており, ジェスチュア表出 以外は軽・中度群の平均値より優れていた。 またジェ スチュア表出の成績も重度群の平均よりはるかに高 く, むしろ, 軽・中度群に近い方の成績であった。言 語の合計点は $60.5 / 230$ (26.3 パーセント) と低いが重 度群の中では上限に近い方の成績である。他の 1 例 $(\mathrm{K} \cdot \mathrm{U})$ は非典型例で, 上と同順に成績を示すと $7 / 16$, $14 / 16,0 / 10,28 / 60,96 / 131$, 言語の合計点 27.5/ 230 (12.0 パーセントで重度群の平均より低い)であっ た.

$\mathrm{K} ・ \mathrm{M}$ がすべての非言語課題でよい傾向があるのに 対して, $\mathrm{K} \cdot \mathrm{U}$ は空間的課題はよいが色塗りは重度群の 平均程度, ジェスチュア表出はゼロと象徵的課題と空 間的課題の成績が解離している点で際立っている。 そ こで失語群でとくに低下する非言語課題があるかを検 討する必要が出てくる. Gainotti は失語症で障害され る非言語的認知機能はシンボルの理解と表出, 概念的 
思考，分類など象徵的機能であって RCPM (レーヴン の色彩マトリックス検查）のような視空間的な知能テ

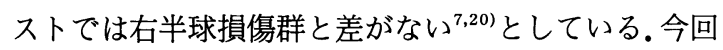
の資料から失語 2 群の非言語課題間の相関をみると, 両群とも象徵的課題と空間的課題間には有意な相関が あった.さらに両群の非言語成績の平均をみると, 軽・ 中度群はすべての非言語能力が高く, 重度群はすべて の非言語成績が低い傾向があり, 失語を群としてみた 場合は, Gainotti の主張を支持しない結果となってい る. 河内 ${ }^{19}$ も色塗りで, Cohen $ら^{21)}$ も色と線画のマッ チング課題で, これらの成績と他の非言語成績との相 関を述べている. しかし個々の症例についてみると, 今回の資料では象徵的課題の能力は低く, 空間的課題 の成績は高いといったように, 非言語能力が解離した $\mathrm{K} \cdot \mathrm{U}$ の例があった。この点で $\mathrm{K} ・ \mathrm{U}$ は Gainotti のさ きの仮説に該当する唯一の例ということができるかも

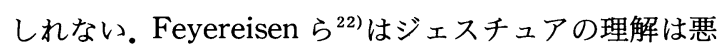
いがその表出はよいという能力解離を示す. 最重度失 語症の例を紹介している.

以上から失語症者を群としてみた場合, 重度群の非 言語能力は軽・中度群に劣るが, 中にはその能力が高 い者もあり, 必ずしも重症度とは対応しない。また非 言語課題の特徴による違いについてみると, 課題が象 徵的か空間的かによって能力が解離しない傾向がある が, まれに, 象徵的課題だけが低い例があることなど が確認された。

痴呆群は象徵的課題は失語軽・中度群レベルで, 空 間的課題は失語重度レベルかそれよりも低かった。ア ルツハイマー病の痴呆の場合, 軽度でも視覚構成障害 が明らかで, その障害の程度によって痴呆の進展を予 測できるといわれる ${ }^{10)}$. 本稿の痴呆群は多発性脳梗塞 による者がほとんどであったが, 病因はともあれ空間 構成能力の低さはこの群の重要な特徵の 1 つと考えら れる. 非言語課題間の相関をみると, 象徵的課題と空 間的課題間には相関がなく同じカテゴリーの課題間に だけ相関がみられた。このことから痴呆群の非言語機 能の様相は失語群とは異なることが推測された.

\section{2. 言語機能と非言語機能の関連}

失語症者の言語と非言語機能をめぐる仮説は, 失語 の重症度との関連について検討した前項でもふれた が, 大きくつぎの 3 種類にわけることができる77.すな わち(1)両機能を司る大脳部位の解剖的近接仮説. した がってこの考え方では非言語機能の低下は合併障害と なる. (2)言語と非言語機能の基底に共通のシステムを 考える仮説. 失象徵の考え方や失語の特定の要素との 機能的関連の主張のほか, さまざまだがこれらの仮説
では非言語機能の低下は合併障害ではなく失語症と不 可分である. (3)言語介在仮説. 非言語課題の解决過程 で言語化しながら課題を遂行するために, 言語能力の 低い失語症者では非言語成績も低くなるとする.

本稿の資料では, 色塗りは聴く・読むの両理解面と の相関が高くなっていた. Gainotti ら ${ }^{20,23)}$ は非言語的 概念障害は語の意味理解と関連しており, 失語の重症 度やタイプには関連がないとし先の(2)に当たる仮説を 立てている。一方, Varney は色塗りやパントマイムの 認知の研究において, 失語症者のこれらの障害は視覚 過程に特定的な情報処理障害であるとしてい $ろ^{24 \sim 26)}$. 本稿の資料でも色塗りは聴理解よりも読みの 理解との関連の方が高い值となっているが，この程度 の差からただちにVarney のような仮説をひき出すこ とは困難であるといわざるを得ない.

著者 3 の資料では上述のように言語理解と非言語的 象徵課題の間に相関があったが, これから直ちに先の Gainotti らの考えを支持できるであろうか. 失語症者 の非言語機能をめぐる考え方のうち合併障害説をとる Vignolo ${ }^{8}$ は, 語の意味障害と非言語的概念障害との関 連を認めながらも，それらが機能的に関連していると するにはまだ証拠不充分としている．そしてこの $2 つ$ の障害の関連は大脳部位の近接仮説でも説明できると している. 本稿の資料で非言語能力がとくに低かった タイプ (後述) の共通損傷部位として左半球の側頭一 頭頂領域が考えられるが, この点を考慮すると Vignolo の説もうなづけるものがり, 失語症者の非言 語機能に関して 1 つの仮説を支持するには, 著者らの 資料はまだ不充分である.

非言語的概念課題と復唱 ${ }^{8,27)}$ や音読 ${ }^{27)}$ との相関の低 さはすでにいわれているところであるが, 著者らの結 果も同じ傾向であった. 先の理解面とは異なって, む しろ意味理解を含まなくとも遂行可能な復唱・音読と の相関の低さは予測されるところである. Basso ら ${ }^{28)}$ は色塗りと呼称の相関を示唆しているが, 今回の資料 では発話面との相関は, 痴呆群では高かったが, 失語 の 2 群ではみられなかった。自発話の過程には意味・ 概念の他に音韻操作能力の問題が加わるために, 対象 とする失語群の特徴によっては, 発話と非言語課題と の相関は低くなると考えられる。

各種のいわゆる動作性知能テストと言語成績の関係 について, 竹内ら ${ }^{16)}$ は聴く・読む・話す面との相関は低 く, 書字や計算との相関が高いという結果を得ている が, 今回の RPM でも同じ結果であった.Gainotti ら ${ }^{20)}$ は RCPM についても意味理解障害との関連を述べて いるが, RPM や RCPM は幾何図形であり, たとえば 
「バナナの色」は「黄色」といったような単純な記号情 報はない. したがってこうした空間的課題の能力と意 味の能力を機能的に関連づけるのは困難と思われる.

彼らもこの仮説では, 非言語的な抽象課題を用いた知 能テストの障害を説明できないとして, 解決過程での 言語介在も示唆している7).

言語課題も非言語課題もその遂行にはおのおの多数 の要因が参加すると想定される. 今回の言語様式と非 言語課題間に得られた相関は, 多数の要因の中の類似 性を持つ一部分ずつが，関連があるものとして表現さ れているとはいうことができるが，その関連の根拠と なる機構についての証拠は, 今後も多くの研究者の成 果に期待せざるを得ない.

\section{3. 非言語機能がとくに低い失語症の特徵}

失語タイプによる差を認める研究では, 全般に全失 語, ウエルニッケ失語の非言語能力は低いとするもの が多い ${ }^{20,28,29)}$. またそれに超皮質性感覚失語を追加す る主張もある ${ }^{8)}$. 本稿の資料も同じ傾向で全失語, 重度 ウエルニッケ失語, 超皮質性感覚失語は非言語能力が 低い者が多かった。 また speechless で理解はある程度 残されているといった最重度のブローカ様失語にもこ の能力が低い者が多い傾向があった。逆に失語が重度 でもブローカ失語の非言語能力は高い者が多く, また 被殸出血による非典型例の中にもこの能力が高い者が 多い傾向があった。

重度群の中でも非言語能力が低い上述の失語群の言 語成績をみると, 多くの課題で非言語能力が軽・中度 群に劣らない重度上群に比較して, 全体的に言語能力 が低くまた読みの理解が有意に悪かった。またこの後 者の結果はさきの 2 項で検討した Varney の主張に類 似のものとなっている.

言語機能も非言語機能も含めて広範囲の領域で能力 が低い失語症者の認知のしかたを知る手がかりとして 色塗りの誤反応の分析をおこなった. 彼らの誤りの量 は, 失語が重度でも非言語能力が低くない群や, 軽・ 中度失語群に比べて, 際立って多かった。しかし誤り の質を解明する手がかりとして調査した保続や未分化 反応の総誤数に占める割合は他の群と有意差がなかっ た。すなわち非言語能力が低い失語症者は多く誤り, 多くの保続・未分化的認知をおこなっているが，その 特徵は他の失語群と異質なものではないようである. しかし以上の誤反応の分析は, 出発点にすぎず, 彼ら の外界認知の様相を明らかにし臨床上の手がかりを得 るためには，さらに詳細な観察が必要であろう。

\section{V. 臨床的意義}

以上，重度失語症者を中心にその非言語機能を検討 し，こうした能力がとくに悪い失語症者の臨床像を明 らかにしてきた．これらの失語症者は臨床的にみると 一般に言語の改善能力が低く，コミュニケーションの 改善に非言語的手段を最も導入したい患者群である. しかしこれまでの検討から，彼らには非言語的手段に よってコミュニケーションを大幅に改善する可能性は ほとんど残されていないと推測された。 Duffy ら ${ }^{12)}$ Cicone $ら^{30)}$ は重度失語症者の代償的コミュニケーシ ヨン手段の獲得は期待できないとし, 逆に Feyereisen ら ${ }^{22)}$ はこれらの患者へのジェスチュア訓練の可能性を 示唆している.また Katz ${ }^{31}$ は患者に特定のジェスチュ アを教えるのではなく，患者が自分のジェスチュアを おこなうのを伸ばすような援助を勧めている。この意 見は臨床的示唆に富むものではあるが，現実にはかな りの困難が予想される。いずれにしろ臨床的に重要な のは失語症の本質をめぐる仮説の適否よりも, 目前の 重度失語症者に ST としてどのような援助が可能かと いう点である.失語症治療における過去 20 年の代用コ ミュニケーション技法を検討した Kraat ${ }^{32}$ は，これら の方法が本当に効果をあげたケースはごくわずかだと し，1990 年代はこうした技法の「反省と再方向づけ」 の時期としている．著者らもまたその感を強くしてい るところである。

堀田ら ${ }^{33}$ は speechless の重度ブローカ失語 2 例を 用いて，実際の会話場面での非言語行動をVTR 録画 から分析し，ほとんど同等レベルの言語成績を示す 2 例の, 使用する非言語手段の象徵性レベルの微妙な違 いを明らかにしている．著者らは本稿において重度失 語症者の非言語能力を検討し, 重度群や,さらにその 下位群の特徴についていくつかの結果を得てきた。こ れらは臨床活動の目安として有用であろうと思われる が, 個々の患者については堀田らの研究が示唆するよ うに，その非言語能力の詳細な観察と，コミュニケー ションへのそれらの適切な導入の努力が必要と思われ る.

本稿をまとめるにあたり，資料の提供をいただいた七沢りハビ リテーション病院脳血管センター言語科, 中村京子氏に深謝いた します。

\section{文献}

1) Holland AL : Communicative Abilities in Daily Living. University Park Press, Baltimore, 1980. 
2) Davis GA, Wilcox MJ : Incorporating parameters of natural conversation in aphasia treatment, In R Chapey (ed) Language Intervension Strategies in Adult Aphasia. Williams \& Wilkins, Baltimore, 1981. 1986. (横山篇, 河内十郎 監訳：失語症言語治療の理論と実際. 創造出版, 1984).

3) Davis GA, Wilcox MJ : Adult Aphasia Rehabilitation : Applied pragmatics. College-Hill, San Diego, 1985.

4）綿森淑子, 竹内愛子, 福迫陽子, 他：実用コミュ ニケーション能力検査 (CADL 検査). 医歯薬出 版, 1990 .

5）河内十郎：脳損傷と象徵過程. 心理学評論, 30 : 88-111, 1987.

6) 河内十郎：失語の象徵機能障害. 失語症研究, 10 : 118-126, 1990.

7) Gainotti G : Nonverbal cognitive disturbances in aphasia, In HA Whitaker (ed) Comtemporary Reviews of Neuropsychology. Springer, New York, 1988.

8) Vignolo LA : Non-verbal conceptual impairment in aphasia, In F Bollor and J Grafman (eds) Handbook of Neuropsychology. Elsevier Science Publishers, Baltimore, 1989.

9) Helm-Estabrooks $N$ : Severe aphasia, In $A L$ Holland (ed) Language Disorders in Adults : Recent Advances. College-Hill, San Diego, 1984.

10) Bayles KA and Kaszniak AW : Communication and Cognition in Normal Aging and Dementia. Taylor \& Francis, London, 1987.

11) Duffy RJ and Liles BZ : A translation of Finkelnburg's (1870) lecture on aphasia as "asymbolia" with commentary. J. Speech Hear. Dis., $44: 156-168,1979$.

12) Duffy RJ, Duffy JR and Pearson KL : Impairment of pantomime recognition in aphasia. J. Speech Hear. Res., 18 : 115-132, 1975.

13) Duffy RJ and Duffy JR : Three studies of defficits in pantomimic expression and pantomime recognition in aphasia J. Speech Hear. Res., 24 : 70-84, 1981.

14) Coelho CA and Duffy RJ : The relationship of the aquisition of manual signs to severity of aphasia : A training study. Brain Lang., 31 : 328
$-345,1987$.

15) Coelho CA and Duffy RJ : Sign aquisition in two aphasic subjects with limb apraxia. Aphasiology, $4: 1-8,1990$.

16）竹内愛子, 河内十郎, 福井图彦, 他: 失語症者に おける言語能力と非言語能力の関係。聴能言語障 害, 2 : 191-202, 1973.

17）竹内愛子, 河内十郎, 福井圀彦: 失語症者の非言 語的認知・構成能力について.リハビリテーショ ン医学, 11 : 93-101, 1974.

18）竹内愛子, 河内十郎 : 失語症患者の非言語能力に ついて.(ことばの障害第 2 巻, 笹沼澄子編: 失語 症とその治療)。大修館書店, 1979 .

19）河内十郎：皮質損傷による色の知覚障害につい て. 東京大学教養学部人文科学紀要, $64: 97-123$, 1977.

20) Gainotti G, D' Erme P, Villa G et al. : Focal brain lesions and intelligence: A study with a new version of Raven's colored matrices. J. clinical Eexp. Neuropyschol., 8 : 37-50, 1986.

21) Cohen $R$ and Kelter $S$ : Cognitive impairments of aphasics in a colour to picture matching task. Cortex, $15: 235-245,1979$.

22) Feyereisen P, Barter D, Goossens $M$ et al. : Gestures and speech in referential communication in aphasic subjects : channel use and efficiency. Aphasiology, $2: 21-32,1988$.

23) Gainotti G, Miceli $G$ and Catagirone $C$ : The relationship between conceptual and semanticlexical disorders in aphasia. Intern. J. Neuroscience, $10:$ 45-50, 1979.

24) Varney NR : Colour association and "colour amnesia" in aphasia. J. Neurosurg. Psychiat., 45 : 248-252, 1982.

25) Varney NR : Pantomime recognition defect in aphasia : Implication for the concept of asymbolia. Brain Lang., 15 : 32-39, 1982.

26) Varney NR and Benton AL : Qualitative aspects of pantomime recognition defect in aphasia. Brain Cog., 1 : 132-139, 1982.

27）大野恭子, 浦上郁子, 神取由美子, 他: 失語症者 における色彩の想起・認知の障害：色塗り検査に よる検討. 失語症研究, 8：291-298, 1988.

28) Basso A, Faglioni and Spinnler H : Nonverbal colour impairment of aphasics. Neuropsychol., 14 : 183-193, 1976. 
29) De Renzi E, Faglioni P, Scotti G et al. : Impairment in associating colour to form, concomitant with aphasia. Brain, 95 : 293-304, 1972.

30) Cicone M, Wapner W, Fordi $\mathrm{N}$ et al. : The relation between gesture and language in aphasic communication. Brain Lang, 8 : 324349, 1979.

31) Katz RC : Gesture and other nonverbal alternatives : A discussion session. Clinical Aphasiology conf., 1980.

32) Kraat AW : Augmentative and alternative com- munication : Does it have a future in aphasia rehabilitation?. Aphasiology, $4: 321-338,1990$.

33）堀田牧子, 竹内愛子：重度ブローカ失語症患者の コミュニケーションの分析：ST との二者間コミ ユニケーションの様態. 第 16 回日本聴能言語学会 学術講演会予稿集, $26,1990$.

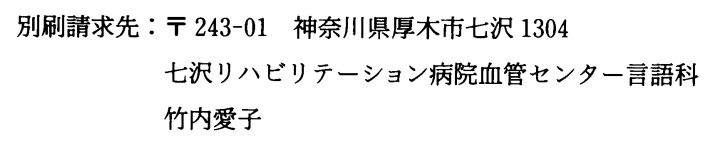

